\title{
AFRICAN HUMAN RIGHTS LAW JOURNAL
}

To cite: SG Damtew 'Land-grabbing and the right to adequate food in Ethiopia' (2019) 19 African

\section{Land-grabbing and the right to adequate food in Ethiopia}

\section{Samrawit Getaneh Damtew*}

Legal researcher, African Union; legal researcher, African Committee of Experts on the Rights and Welfare of the Child, Addis Ababa, Ethiopia

https://orcid.org/0000-0003-2231-1558

\section{Summary}

The post-2008 global land rush was mainly targeted at Africa. With its weak system of governance and abundant arable land and water resources, Ethiopia has been and remains one of the hotspots for landgrabbing in Africa. Land-grabbing has various negative consequences for the human rights of rural communities. Due to the link between food security and land-grabbing, the right to adequate food is the human right most affected. The right to adequate food requires states to refrain from depriving people of access to natural resources that they use to feed themselves; this includes land and water. Although the right to food is progressively realised, the duty not to take retrogressive measures is immediate. As the custodian of the land under the 1995 Constitution the Ethiopian government has since directly concluded deals with investors, displaced communities, and given away land previously used by Ethiopian farmers to the new foreign lessees. Since land-grabbing mainly affects the agrarian rural community, the article analyses the phenomenon of landgrabbing against the type of agriculture practised in Ethiopia, climate change and coping mechanisms of communities, and the livelihood of pastoralists and indigenous people. It demonstrates how land-grabbing is antithetical to the right to adequate food in the context of Ethiopia.

Key words: land-grabbing; right to food; socio-economic rights; Ethiopia

* LLB (Addis Ababa) LLM (Pretoria); SamrawitGetanew@africa-union.org 


\section{Introduction}

In 2008 the world experienced a financial crisis and a steep rise in the price of agricultural produce. ${ }^{1}$ Certain Asian and Middle Eastern countries faced a shortage of land and water resources. ${ }^{2}$ Furthermore, new quotas for the use of agro-fuels in the European Union (EU) and the United States (US) triggered these countries and their various corporations to look for offshore arable land. ${ }^{3}$ This has led to the acceleration of the phenomenon of international large-scale acquisition of land with the aim of ensuring food security, among other things. ${ }^{4}$ Various terms are used to describe this land acquisition, including the global land rush, land-grabbing and international land deals. In the article the term 'land-grabbing' is used as the author attempts to highlight the impact of the phenomenon on human rights, specifically on the right to adequate food.

Land-grabbing is defined as the acquisition or lease of relatively large tracts of land along with water and mineral resources by transnational or domestic corporations or investors, to produce food and bio-fuel for international or domestic markets. This largely occurs with no prior consultation with or consent of the local communities that used the land, and without adequate compensation. ${ }^{5}$ The real extent of the scale of land-grabbing is not known due to the level of obscurity in which it is done. The World Bank reported that before 2008 the average annual large-scale farm land deals globally covered an area of approximately 4 million hectares. However, by the end of 2009 , in the wake of the global financial, food and energy crisis, more than 56 million hectares of land deals were declared, 70 per cent of which was in Africa. ${ }^{6}$ A study conducted by Oxfam in 2012 indicated that 230 million hectares of land, an area the size of Western Europe, has been sold or leased as from 2001, most of it having taken place in 2008. ${ }^{7}$

Land-grabbing continues to be an important global issue. ${ }^{8}$ Africa remains the main target of the global land rush. The phenomenon has

1 S Cardenas 'IMF survey: Global slowdown damages progress in low-income countries' (2009) https://www.imf.org/en/News/Articles/2015/09/28/04/53/sone w012309a (accessed 15 September 2016).

2 Oakland Institute Understanding land investment deals in Africa: Ethiopia (2011) 3.

3 As above.

4 As above.

5 ME Margulis, N McKeon \& SM Borras Land-grabbing and global governance: Critical perspectives (2014).

6 K Deininger \& D Byerlee 'Rising global interest in farmland: Can it yield sustainable and equitable benefits?' (2011) The World Bank xiv.

7 Oxfam Land and power: The growing scandal surrounding the new wave of investments in land (2011) 5.

8 K Nolte, W Chamberlain \& M Giger International land deals for agriculture. Fresh insights from the land matrix: Analytical report II' (2016) vi. 
been described by some as a 'neo-colonialist scramble for Africa'. 9 of the few sub-Saharan countries that are targeted mainly by foreign investors, Ethiopia is prominent and is being described as the epicentre for land-grabbing. ${ }^{10}$ Land-grabbing has raised various concerns and issues. One of these concerns is its negative impact on food security and, consequently, the right to adequate food.

The article aims to demonstrate the link between land-grabbing and the right to food in the context of Ethiopia, and challenges this phenomenon using the right to food. Part 2 briefly highlights factors influencing land-grabbing in the socio-geographical and economic background of Ethiopia with a focus on the agricultural sector. Part 3 elaborates on the content of the right to food at international, regional and national levels. It expounds on the obligations of states and measures that ought to be taken in implementing the right to food. It explores the extent of the recognition of the right and its justiciability in Ethiopia. The last part of the article is dedicated to exploring how a right to food approach can be used to address the impact of land-grabbing. It elaborates on how the different stages of land-grabbing threaten the right to food, starting from the negotiation stage and the conclusion of the deal up to displacement and loss of livelihoods. The article concludes by making recommendations to the government of Ethiopia on measures that ought to be taken.

\section{Land-grabbing in Ethiopia}

\subsection{Role of land in Ethiopia}

Ethiopia, one of the poorest countries in the world which is dependent on international food aid, experiences some of the largest international land-grabs. ${ }^{11}$ Agriculture is the most important sector in the country. It accounts for 85 per cent of total employment, contributes approximately 50 per cent to the gross domestic product (GDP) and 85 per cent to exports. ${ }^{12}$ This makes agricultural land the most significant economic asset of the county. The agricultural sector is heavily dependent on rainfall. This has made the country prone to recurring droughts and famine. ${ }^{13}$ In early 2016 Ethiopia was hit by its

9 L Cochrane 'Food security or food sovereignty: The case of land grabs' (2011) The Journal of Humanitarian Assistance 5.

10 As above.

11 ActionAid Lay of the land: Improving land governance to stop land grabs (2012) 27.

12 J Keeley et al Large-scale land deals in Ethiopia: Scale, trends, features and outcomes to date (2014) 10.

13 World Food Programme 'Drought in Ethiopia: 10 million people in need' https:// www.wfp.org/stories/drought-ethiopia-10-million-people-need (accessed 15 September 2016). 
worst drought in 50 years, leaving more than ten million people in need of urgent humanitarian assistance. ${ }^{14}$

Land is the entry point for the realisation of various human rights. Access to food is closely tied to the availability of land on which to grow crops and rear livestock. ${ }^{15}$ More than 80 per cent of the Ethiopian population is classified as smallholders, farming an area of one hectare on average. ${ }^{16}$ However, the government's strategy for the country's development is focused on large-scale land investment. ${ }^{17}$ In 1996 the incumbent Ethiopian People's Revolutionary Democratic Front (EPRDF) government launched the Agricultural Development-Led Industrialisation (ADLI) as a national strategy, which foresaw the progression towards the large-scale commercialisation of farm land. 18 The commercialisation of smallholder farms and the development of bio-fuels are now a part of the development strategy. ${ }^{19}$ To this end the government has designed a favourable investment environment to attract direct foreign investment on agriculture. ${ }^{20}$

The development strategy resulted in the creation of federal land banks for priority investments. It included an incentive of a five-year tax holiday for agricultural investors who export at least 50 per cent of their produce. ${ }^{21}$ In 2009 the Agricultural Investment Support Directorate (AISD) was established under the Ministry of Agriculture and Rural Development (MoRAD). This was done in response to the growing commercial demand for farm land in Ethiopia. ${ }^{22}$ One of the tasks of AISD is to identify and demarcate potential arable land for investment. Accordingly, of the nine regions of Ethiopia the Directorate identified land for agricultural investment in five regions, leaving the other four regions to do the delineation themselves. ${ }^{23}$ Consequently, AISD identified 3673806 hectares of land in five regions (Oromia, Benishangul Gumuz, Gambella, Southern Nations, Nationalities and Peoples Region/SNNPR, Afar and Somalia) for

14 As above.

15 'Ethiopia: Land-grabbing is a human rights violation, no land, no life!' http:// www.durame.com/2016/01/ethiopia-land-grabbing-is-human-rights.html (accessed 13 October 2016).

16 Country Pasture/Forage Resource Profiles: Ethiopia http://www.fao.org/ag/agp/ agpc/doc/counprof/ethiopia/ethiopia.htm (accessed 4 October 2016).

17 J Abbink 'Land to the foreigners: Economic, legal, and sociocultural aspects of new land acquisition schemes in Ethiopia' (2011) 29 Journal of Contemporary African Studies 515.

18 As above.

19 As above.

20 Federal Democratic Republic of Ethiopia Ministry of Agriculture and Rural Development Ethiopia's agricultural sector policy and investment framework 20102020 (2010) 10.

21 F Makki \& C Geisler Development by dispossession: Land-grabbing as new enclosures in contemporary Ethiopia (2011) 13.

22 M Fisseha $A$ case study of the Bechera agricultural development project, Ethiopia (2011) 9.

23 As above. 
agricultural investment. ${ }^{24}$ The Federal government removed the negotiation right ${ }^{25}$ regarding land deals that are above 1000 hectares from regional states. Hence, deals are concluded between investors and the federal government. ${ }^{26}$

The aforementioned development strategy led to unprecedented levels of investment in farm land in Ethiopia. The World Bank reported that an estimate of 406 commercial investment projects, covering one million hectares of land, were signed in Ethiopia by 2011.27 By 2016 approximately half a million hectares of land have been given to foreign investors for the production of food crops alone. This figure excludes land deals that were cancelled and that are less than 500 hectares in extent. ${ }^{28}$ In total, seven million hectares of land, equal to the size of Belgium, has since 2007 been transferred to investors. ${ }^{29}$ More than one million of these went to foreign investors. ${ }^{30}$ The land grabs are done mostly without any kind of prior consultation and without adequate compensation, sometimes with no compensation, to the evicted farmers and community members. ${ }^{31}$ Land is leased to investors at a rental of approximately US $\$ 2$ per hectare per year. ${ }^{32}$ This amounts to one of the lowest rentals globally. ${ }^{33}$ According to government data, most of the land deals that are concluded involved land that is considered not to have any pre-existing users and labelled 'wasteland' 34 However, the reality in various communities indicates otherwise. ${ }^{35}$ What the government regards as 'wasteland' is land

24 Ministry of Agriculture Agricultural investment opportunities in Ethiopia (2013) 2.

25 Art 52 of the FDRE Constitution gives the power of administering land and other natural resources to regional states. Accordingly, before the establishment of the AISD, the regional states allotted agricultural land to investors according to their own criteria. However, after the establishment of AISD the Federal Government centralised the administration and management of regional lands in the Federal Land Bank. See RA Nalepa et al 'Marginal land and the global land rush: A spatial exploration of contested lands and state-directed development in contemporary Ethiopia' Geoforum (2016) 4 http://dx.doi.org/10.1016/j.geoforum.2016.10.008 (accessed 4 October 2016).

26 Abbink (n 17) 517.

27 D Vhugen \& A Gebru Large-scale acquisitions of land in Ethiopia (2012) 2.

28 GRAIN The farmland grab in 2016: How big? How bad? (2016) 41-45.

29 GRAIN 'Land grab deals' https://www.grain.org/article/entries/4479-grain-releases -data-set-with-over-400-global-land-grabs (accessed 1 October 2016).

30 As above.

31 Oakland Institute (n 2) 36.

32 The High-Level Panel of Experts on Food Security and Nutrition Land tenure and international investments in agriculture (2011) 30.

33 As above.

34 Future Agriculture Land-grabbing in Africa and the new politics of food (2011) 3.

35 Nalepa et al (n 25) 3 5-8; see also A Demena 'The tragic of land-grabbing for biofuels in Ethiopia' (2016) https://ecadforum.com/2016/03/07/the-tragic-truth-ofland-grabbing-for-biofuels-in-ethiopia/ (accessed 1 October 2016). See also M Jaatee \& Z Mulataa 'Review of land-grabbing policies of successive regimes of Ethiopia (The major external factor challenging national liberation struggle of peoples of Oromia and Southern Ethiopia)' (2012) 23 http://gadaa.com/Oromo Studies/wp-content/uploads/2012/12/A-final-review-of-land-grabbing-policies-ofsuccessive-regimes-of-Ethiopia-1.pdf (accessed 1 October 2016). See also 
utilised for shifting cultivation, grazing and pastoralism. ${ }^{36}$

This open door policy for agricultural investment in Ethiopia that has led to land-grabbing is sustained by various justifications. The government claims that apart from ameliorating food security, the investments will facilitate technology transfer, create employment, and develop infrastructure. ${ }^{37}$ However, there is no data to show the achievements of these benefits or the future possibility thereof. There has been no sign of technology transfer as most smallholders continue to use low-technology farming techniques. Furthermore, it is unclear how large-scale commercial farming that uses intensive capital, herbicides and pesticides, intensive irrigation and large-scale machinery can result in technology transfer to economically-poor smallholders. ${ }^{38}$ In terms of infrastructure, the country is undergoing massive infrastructural development in all areas. However, investor-led infrastructure development is insignificant in scale. ${ }^{39}$ Most investors are comfortable with the existing infrastructure and do not see the need to become involved. ${ }^{40}$ Some of the land investments have led to the employment of locals; however, the wages range from 10 to 20 Ethiopian birr, which is an average of US $\$ 1$ per day. ${ }^{41}$ This is below the latest global poverty line and the national poverty line of Ethiopia. ${ }^{42}$

\subsection{Impact of land-grabbing on food security in Ethiopia}

Ethiopia has in recent history experienced several droughts and famines. Climate change and the reliance of small-scale farmers on rain-dependent agriculture are the main causes of droughts. ${ }^{43}$ Various strategies have been implemented to fight hunger. ${ }^{44}$ However, in

RA Nalepa 'Land for agricultural development in the era of "land-grabbing": A spatial exploration of the "marginal lands" narrative in contemporary Ethiopia' LDPI Working Paper 40 (2013) 17 14-17 https://www.iss.nl/sites/corporate/files/ LDPI_WP_40.pdf (accessed 1 October 2016).

36 L Cotula Land deals in Africa: What is in the contracts? (2011) 16.

37 Oakland Institute (n 2) 34.

38 As above.

39 As above.

40 As above.

41 Oakland Institute (n 2) 35.

42 D Espen \& B Prydz Estimating international poverty lines from comparable national thresholds (2016) 2.

43 A Sen Poverty and famines: An essay on entitlement and deprivation (1981) 88.

44 The Ethiopian Rural Development Policy and Strategy, which aimed to eliminate dependence on food aid set out the following directions: (1) developing and utilising the knowledge and skills of the country's human resources; (2) effectively exploiting the land resources; (3) preparing and implementing environment and eco-system compatible rural development package; (4) ascertaining market-led agricultural development; (5) improving the rural financial systems; (6) encouraging the private sector to invest in agricultural development; (7) expanding rural development; (8) strengthening other non-agricultural rural based economic activities; http://extwprlegs1.fao.org/docs/pdf/eth144892.pdf (accessed 1 October 2016). The National Growth and Transformation Plan of the country 2010-2015 required the adoption of Climate-Change-Resilient 
2016 the country faced the worst drought in 50 years, with 10,2 million people estimated to have been in need of emergency food aid. This was in addition to the approximately 8 million people who are on constant annual food aid programmes run by the government. ${ }^{45}$ Even though droughts in Ethiopia are caused by a lack of rainfall, the drought leads to famine due to entitlement failure. ${ }^{46}$ Moreover, recent threats of famine in the country result from a shortage in national food production and entitlement failure. ${ }^{47}$ In previous famines, pastoralists were among the groups most affected. This is not only due to drought but also largely due to displacement from their

Green-Agricultural development in an endeavour to increase productivity and produces. http://extwprlegs1.fao.org/docs/pdf/eth144893.pdf (accessed 1 October 2016). The report of the 2017 Voluntary National Reviews on SDGs of Ethiopia noted the following on SDG Goal 2: end hunger, achieve food security and improved nutrition and promote sustainable agriculture. The supply of agricultural inputs increased in 2014/2015. In 2015/2016, agricultural extension services given to the farming and pastoral communities reached 15791000 households. Small-scale irrigated agriculture is expanded following and in observance of climate change resilient green agricultural development. Sustainable natural resources management system were utilised; the government also encouraged the private sector to invest in agro-ecology compatible agriculture; agricultural inputs identified through agricultural research have been supplied to increase the national agricultural productivity and to increase the volume of agricultural produces. Moreover, it was noted that climate changecaused drought that occurred in the 2015/2016 and 2016/2017 financial years has had a severely adverse impact on the agricultural sector in particular. Drought victims in 2014/2015 were 10,2 million while in 2016/2017 the drought lingered on but the number of victims was reduced to 5,2 million. Consequently, the national performance target set for volume of agricultural produce for the financial year 2015/16 was reduced by 5,9\%. Livestock resources were severely impacted. The volume of main food crops produced reduced from the volume produced in 2014/2015. Meat produces reduced to 669000 tons from the tonnage produced in 2014/2015 which was 1321000 tons. The volume of milk produced also reduced. https://sustainabledevelopment.un.org/content/ documents/16437Ethiopia.pdf (accessed 1 October 2016).

45 World Food Programme 'Ethiopia: Current issues and what the World Food Programme is doing' https://www.wfp.org/countries/ethiopia (accessed 3 October 2016).

46 Entitlement failure is a concept coined by Amartya Sen to explain the cause of famine beyond food shortage. The concept envelopes three sets of elements. The first, a set of endowment, is defined as the combination of all resources legally owned by a person The entitlement set is defined as the set of all possible combinations of goods and services that a person can legally obtain by using the resources of his/her endowment set. For example, a farmer may use his land, labour, and other resources to produce the food he wants; a labourer may exchange his labour power to secure his food. Entitlement mapping shows the rates at which the resources of the endowment set can be converted into goods and services included in the entitlement set. A person is said to suffer from the failure of food entitlement/entitlement failure when his/her entitlement set does not contain enough food to enable her/him to avoid starvation in the absence of non-entitlement transfers, such as charity. A famine occurs when a large number of people within a community suffer from such entitlement failures at the same time. See S Osmani 'The entitlement approach to famine: An assesement' The United Nations University (1993) 3-5 https://www.wider.unu.edu/sites/default/ files/WP107.pdf (accessed 1 October 2016).

47 S Devereux et al Famine: Lessons learned (2017) 17. 
lands for expansion of commercial agriculture. ${ }^{48}$ This rendered them vulnerable to starvation as the land they were displaced from had served as their backup for the long dry season to be used as grazing land. ${ }^{49}$

The government has stressed its commitment to reducing poverty and increasing food security. However, land-grabbing in reality is exacerbating the already existing hunger and desperation in vulnerable communities. In regions where there is little food security, local communities have developed coping mechanisms such as shifting cultivation, farming in sedentary plots along river banks and relying on forest resources. ${ }^{0}$ Land-grabbing in these areas has led to the clearing of forests and shifting of cultivation plots that are crucial buffers for the food security of local stallholders. ${ }^{51}$ Furthermore, since investors target land that is close to water, land-grabs hinder access to water for consumption as well as threaten farms on sedentary plots along river lines. ${ }^{52}$

Some areas in the country experience seasonal flooding from rivers. To cope with this, a system of flood retreat agriculture is practised, whereby in the drier season farmers cultivate land on river banks and in rainy seasons they cultivate away from river banks. This practice is predominant in the SNNPR and Gambella regions. ${ }^{53}$ The dry season plots in the Gambella region cover seven communities and the land of all communities of the SNNPR regions have been seized by investors. This has led the majority of community members in Gambella and SNNPR to apply for food aid in order to offset lost production. ${ }^{54}$

The situation is further aggravated by the emphasis on the export of food. Large-scale agricultural investors are encouraged and given incentives by the Ethiopian government to export their produce, 55 sacrificing food security for foreign exchange. This is more than welcomed by foreign investors whose target already was the foreign market. It further pushes local investors to export crops in order to benefit from government incentives. As ironic as it sounds, the country in which millions of people depend on international food aid for survival now predominately exports food and cash crops. ${ }^{56}$

48 E Elias Pastoralists in Southern Ethiopia: Dispossession, access to resources and dialogue with policy makers (2008) 11-19.

49 As above.

50 Oakland Institute (n 2) 36.

51 As above.

52 D Rahmato 'Land to investors: Large-scale land transfers in Ethiopia' (2011) Forum for Social Studies 21.

53 G Schoneveld The governance of large-scale farmland investments in sub-Saharan Africa: A comparative analysis of the challenges for sustainability (2013) 69.

54 As above.

55 Rahmato (n 52) 9.

56 Ethiopia's top 10 exports http://www.worldstopexports.com/ethiopias-top-10exports/ (accessed 10 September 2016). 
A study conducted on the impact of land-grabbing in the Gambella region, a hotspot for investors, reveals that thousands of people are displaced from their fertile lands and relocated to mostly dry and poor quality lands. ${ }^{57}$ More than 42 per cent of the total land is either under negotiation for lease or has already been leased to investors. ${ }^{58}$ By 2014 more than 420 large-scale land deals were registered in the Gambella region. ${ }^{59}$ Many of the displaced communities face hunger, some to the extent of starvation. ${ }^{60}$ Communities that were once able to feed themselves are rendered hopeless recipients of food aid, if available. ${ }^{61}$ Shifting cultivators, who cultivate land in different locations as a coping mechanism for climate change, were forced to settle on a single crop and pastoralists are forced to abandon their cattle. $^{62}$ The relocation of people is done under the infamous 'villagisation' programme of the government, which is alleged to be aimed at improving the socio-economic situation of the community by bringing them closer to health care, educational and other service facilities. ${ }^{63}$ However, instead of getting the promised improved access to government services, communities are left to starve. ${ }^{64}$ Furthermore, the villagisation programme is conducted by force, where those who refuse to be relocated are beaten up and arrested. ${ }^{65}$

Even when a land-grab does not directly result in the displacement of farmers from their land, it has adverse consequences on the food security of the local communities. A study conducted in the Oromia region on the Bercha Agricultural Development Project, owned by an Indian company called Karaturi Agro PLC, indicates these consequences. ${ }^{66}$ The government leased 10700 hectares of land for 30 years to the company for the purpose of the agricultural project. The project aims to produce food crops to be exported to India. The land that was given to the company used to be the communal grazing land of the inhabitants of the area. ${ }^{67}$ The community decided to use the land for communal grazing after realising that the increase in cultivation was threatening the sustainability of their livestock. However, the government leased the land under the pretext that it was idle, non-cultivated land. ${ }^{68}$ The loss of the grazing area and the

57 Human Rights Watch 'Waiting here for death': Forced displacement and 'villagisation' in Ethiopia's Gambella region (2012) 2.

58 As above.

59 F Gebresenbet 'Land acquisitions, the politics of dispossession, and state-remaking in Gambella, Western Ethiopia' (2016) Africa Spectrum 12.

60 Oakland Institute Unheard voices the human rights impact of land investments on indigenous communities in Gambella (2013) 5.

61 As above.

62 As above.

63 As above.

64 As above.

65 Oakland Institute (n 60) 7.

66 ILC \& CIRAD A case study of the Bechera agricultural development project, Ethiopia (2011) 1 .

67 ILC \& CIRAD (n 66) 11.

68 ILC \& CIRAD 34. 
resulting drastic decrease in the availability of fodder forced the majority of the members of the local community to sell their livestock, thereby threatening their livelihood. ${ }^{69}$ Furthermore, a roadblock constructed by the company has blocked access to rivers and other water sources used by locals. In addition, a deep ditch dug alongside the commercial farm has blocked the way to the nearby Gibe River which previously was used by farmers to water livestock. ${ }^{70}$ Newly-wed couples that are starting a family were unable to get land for farming. Alternatively, they practise share-cropping on a very small land with a share of 50 per cent on average, which does not earn them enough to survive a year. ${ }^{71}$

The company promised to dig water wells and construct schools and clinics for the community, but none of this materialised. ${ }^{72}$ The only benefit to the community was that a few persons were employed as guards and others were employed seasonally (only for a few months in a year) as skilled labourers. They earn salaries of approximately $\$ 2$ dollars per day as skilled labourers and about $\$ 0,5$ per day as non-skilled workers. ${ }^{73}$

Apart from smallholder farmers and pastoralists, another group that is gravely impacted by this phenomenon are indigenous people. ${ }^{74}$ There are several indigenous communities in Ethiopia, among them small communities living along the Omo Valley of the SNNPR region. ${ }^{75}$ The indigenous communities of the Omo valley, ${ }^{76}$ especially, have faced various human rights violations through the establishment of 100000 hectares of private commercial farming and other large developmental projects. ${ }^{77}$ Communities of the Omo Valley rely mainly on the Omo River for growing crops and replenishing grazing land. ${ }^{78}$ They have been subjected to a forced villagisation programme accompanied by arbitrary detention, beatings and intimidation. ${ }^{79}$ Indigenous communities of the Omo Valley have been displaced from their ancestral lands, forced to reduce the number of their cattle, abandon the Omo River and shift to a sedentary lifestyle. ${ }^{80}$

69 ILC \& CIRAD 42.

70 ILC \& CIRAD 36.

71 ILC \& CIRAD 33.

72 As above.

73 ILC \& CIRAD (n 66) 28.

74 Advisory Opinion of the African Commission on Human and Peoples' Rights on the United Nations Declaration on the Rights of Indigenous Peoples (2007) 4.

75 ACHPR \& IWGIA 'Report of the ACHPR Working Group of Experts on Indigenous Populations/Communities' (2005) 18.

76 The communities that are directly affected include the Mursi, Suri, Kwegu, Daasanach, Nyangatom, Karo, Hamer and Bodi indigenous people.

77 Human Rights Watch 'What will happen if hunger comes?' Abuses against the indigenous peoples of Ethiopia's Lower Omo Valley (2012) 2.

78 As above.

79 Human Rights Watch (n 77) 48.

80 As above. 
Land-grabbing for commercial agriculture and other projects are projected to affect the livelihood of approximately 200000 people in the Omo Valley of Ethiopia. ${ }^{81}$ It is estimated that a total number of 270000 indigenous people have been forcefully displaced from the Omo valley and western Gambella regions. ${ }^{82}$ The forced changes in lifestyle, reduced access to water resources and lack of adequate compensation have rendered the communities vulnerable to hunger. ${ }^{83}$

\section{Right to adequate food}

As the right most affected by land-grabbing, the right to food requires closer inspection. Below I elaborate the elements of the right to food, starting from international and regional treaties up to the national recognition of the right in Ethiopia. The various levels of state obligations are explained along with the justiciability of the right in Ethiopia.

The right to adequate food is founded in international human rights law. It has been incorporated in the Universal Declaration of Human Rights (Universal Declaration). The Declaration states in article 25 that '[e]veryone has the right to a standard of living adequate for the health and well-being of himself and of his family, including food'. ${ }^{84}$ The right to adequate food was later incorporated, in a similar fashion, in article 11 of the International Covenant on Economic, Social and Cultural Rights (ICESCR). The Covenant, which is a binding instrument, reiterated the right to adequate food and included the fundamental right to be free from hunger. Freedom from hunger is the only right in ICESCR identified as fundamental, indicating the vital nature of the right as it is a basic necessity for life. ${ }^{85}$ Article 11 further enumerates states' obligations in the implementation of the right. Among other things, state parties have an obligation to take measures to improve methods of production, conservation and distribution of food by making full use of technical and scientific knowledge. Furthermore, state parties have an obligation to take measures to ensure an equitable distribution of world food supplies in relation to need.

Despite its early explicit recognition, the right was seldom invoked on the international platform. In fact, the first time the right to food

\footnotetext{
81 Human Rights Watch (n 77) 1.

82 M Jaatee 'Land-grabbing and violations of human rights in Ethiopia' (2016) http:// www.farmlandgrab.org/post/view/25706-land-grabbing-and-violations-of-humanrights-in-ethiopia (accessed 1 October 2016).

83 As above.

84 Art 25 Universal Declaration.

85 Art 11 ICESCR.
} 
was raised was at the 1996 World Food Summit. ${ }^{86}$ The Summit was held in response to the sharp increase in the price of cereals, widespread undernourishment and a sharp decline in international food aid. ${ }^{87}$ At the Summit world leaders demanded that the right to food contained in ICESCR be further clarified and given teeth. The main reason for invoking the right to food at the time was the fact that despite growing technology and increasing food availability per person, globally more than 800 million people remain hungry. ${ }^{88}$

Following the Summit, the Committee on Economic, Social and Cultural Rights (ESCR Committee) adopted a General Comment clarifying the right to food, in response to the request made. ${ }^{89}$ General Comment 12 clarified the right to food and outlined the three levels of obligations of states in relation to the right. In clarifying the right to food, the Committee stated that the right should be realised progressively. It identified the core content of the right to be

the availability of food in a quantity and quality sufficient to satisfy the dietary needs of individuals, free from adverse substances, and acceptable within a given culture; the accessibility of such food in ways that are sustainable and that do not interfere with the enjoyment of other human rights. ${ }^{90}$

All the elements of the core content of the right are very important and hence they were elaborated further. Availability was defined to include 'feeding oneself directly from productive land or other natural resources'. 91 This outlook of availability places in perspective the importance of land rights in the realisation of the right to food, especially for those whose livelihood is related closely to the use of land.

The ESCR Committee identified three levels of obligations placed on governments in relation to the right to food. These are the obligation to respect, which entails refraining from arbitrary interference with the enjoyment of the right; ${ }^{92}$ the obligation to protect, which relates to the duty of ensuring that the right is not infringed upon by third parties; ${ }^{93}$ and the duty to fulfil, which incorporates the duty to facilitate and provide food. The duty to facilitate food entails enabling the enjoyment of the right by strengthening access to resources and means to ensure livelihoods, and ensure food security. The duty to provide food demands the

86 World Food Summit 1996 http://www.fao.org/docrep/×2051e/x2051e00.htm\# p83_5958 (accessed 6 October 2016).

87 As above.

88 As above.

89 ESCR Committee General Comment 12.

90 General Comment 12 para 8.

91 General Comment 12 para 12.

92 General Comment 12 para 15.

93 As above. 
provision of food when people are not in a position to feed themselves owing to situations beyond their control. ${ }^{94}$ In undertaking their duty to respect, protect and fulfil the right to food, states are expected to comply with the principles of participation, the rule of law, accountability and transparency. ${ }^{95}$

Regionally, the African Charter on Human and Peoples' Rights (African Charter) does not explicitly recognise the right to food. However, the progressive jurisprudence of the African Commission on Human and Peoples' Rights (African Commission) has made the incorporation of the right to food possible. In its decision in SERAC ${ }^{96}$ the Commission stated that the right to food was an implied right in the African Charter. ${ }^{97}$

The right to food is closely related to several other rights. The right to property, which includes access to land, is one of these rights. The jurisprudence of the African Commission indicates that the right to property, which is enshrined in the African Charter, includes the right to land. ${ }^{98}$ Furthermore, the Protocol to the African Charter on Human and Peoples' Rights on the Rights of Women in Africa (African Women's Protocol) explicitly recognises the right to food security of women and imposes on states the obligation to take measures to provide women with access to land and other resources for food production. ${ }^{99}$

\subsection{Right to food in Ethiopia}

The right to food is not explicitly recognised in the Constitution of Ethiopia. However, Ethiopia has ratified both ICESCR and the African Charter. 'All international agreements ratified by Ethiopia are an integral part of the law of the land. ${ }^{100}$ As such, the protections provided in ICESCR and the African Charter are important normative guarantees in the Ethiopian legal framework. Furthermore, fundamental rights provided for in the Constitution have to be 'interpreted in a manner conforming to the principles of ... international instruments adopted by Ethiopia'. ${ }^{101}$ Hence, where the interpretation of domestic law is involved, international treaties serve as authoritative guidelines.

\footnotetext{
94 As above.

95 C Golay \& I Biglino 'Human rights responses to land-grabbing: A right to food perspective' (2013) 34 Third World Quarterly 1632.

96 Social and Economic Rights Action Centre (SERAC) \& Another v Nigeria (2001) AHRLR (ACHPR 2001) (SERAC).

97 SERAC (n 96) para 64.

98 Malawi African Association \& Others v Mauritania (2000) AHRLR 149 (ACHPR 2000) para 128.

99 Art 15(a) African Women's Protocol.

100 Art 9 FDRE Constitution.

101 Art 13 FDRE Constitution.
} 
Food is mentioned in the Constitution not as a right but as a social objective that is subject to resource availability. ${ }^{102}$ However, the land rights of peasants and pastoralists to access farming and grazing land without payment and their protection from eviction are recognised in the Constitution. 103 This recognition is important for the realisation of the right to food in the context of land-grabbing. Moreover, the recognition of a right is not enough to ensure protection, unless one is able to enforce it in a court of law. Hence it is critical to examine the justiciability of the right to food in Ethiopia.

\subsection{Justiciability of the right to food in Ethiopia}

A right is said to be justiciable if it can be subjected to trial in a judicial or quasi-judicial body. ${ }^{104}$ The unnecessary controversy about the justiciability of socio-economic rights is not peculiar to the Ethiopian legal system. Some argue that socio-economic rights are not justiciable in Ethiopia as they are incorporated in the National Policy Principles and Objectives. ${ }^{105}$ However, all the elements necessary for the justiciability of the right to food in Ethiopia have been fulfilled. First, the right to food is recognised by virtue of its inclusion in treaties ratified by Ethiopia as an integral part of the national law. ${ }^{106}$ In this regard, the doubt surrounding the direct applicability of international instruments in the domestic courts of Ethiopia has been put to rest by the landmark decision of the Cassation Division of the Federal Supreme Court in the Demissie case, where the Convention on the Rights of the Child (CRC) was applied directly. ${ }^{107}$ The second element is the existence of a competent and impartial judicial or quasi-judicial body with the power to entertain allegations of the violation of the right. Indeed, courts have the constitutional power to interpret and enforce all laws in Ethiopia. ${ }^{108}$ The third element is the existence of a remedy. There are several possible remedies for different types of violations of the right to food. Right to food litigation in the Supreme Court of India is an example of how a violation of the right may be argued and the possible remedies that may be rendered. ${ }^{109}$ Even though the Constitution of India does not explicitly incorporate the right to food, the Supreme Court of India has stated in the wellknown People's Union for Civil Liberties case that the right to food is part of the right to life. In this case it was alleged that the government

102 Art 90 FDRE Constitution.

103 Arts 40(4) \& (5) FDRE Constitution.

104 A Tesfaye 'Justiciability of socio-economic rights in the Federal Democratic Republic of Ethiopia' unpublished LLM thesis, Addis Ababa University, 201011.

105 Tesfaye (n 104) 51.

106 S Yeshanew 'The justiciability of human rights in the Federal Democratic Republic of Ethiopia' (2008) 8 African Human Rights Law Journal 276.

107 Miss Tsedale Demissie v Mr Kifle Demissie (2006) 23632 (Federal Supreme Court of Ethiopia Cassation Division).

108 Art 79(1) FDRE Constitution.

109 International Development Law Organisation Realising the right to food legal strategies and approaches (2014) 39. 
of India had violated the right to food by failing to distribute the available food stock to drought-affected citizens. ${ }^{110}$ In an interim order, the Indian Supreme Court ordered the government to provide food for vulnerable communities in areas of scarcity and to implement a system of transparency and the creation of awareness of assistance programmes. ${ }^{111}$

However, the role of Ethiopian courts in adjudicating human rights matters remains to be seen, owing to various factors. Their function as custodians of human rights has been shifted to other organs, namely, the House of Federation, which is a political body, and the Council of Constitutional Inquiry. ${ }^{112}$ Moreover, when it comes to the right to food, no court case has as yet alleged the violation of the right. 113 In the history of the country, hundreds of thousands of people have died due to famine that could have been averted through government action. Moreover, to date every year millions of people depend on food aid for their survival and thousands are forced into hunger as a result of government policies and actions. Despite these facts, so far no court case has been brought alleging the violation of the right to food. ${ }^{114}$

110 PUCL $v$ Union of India \& Others http://www.hrln.org/hrln/right-to-food/pils-acases/255-pucl-vs-union-of-india-a-others-.html (accessed 23 October 2016).

111 People's Union for Civil Liberties v Union of India \& Others (2001) 1964 \& 5 (Supreme Court of India Interim Order of 2 May 2003).

112 AK Abebe 'Human rights under the Ethiopian Constitution: A descriptive overview' (2011) 5 Mizan Law Review 65-69.

113 Many reasons can be given as to why the right to food has not been a subject of court proceedings. Some argue that socio-economic rights are not justiciable. However, I have noted in this section that socio-economic rights, specifically the right to food, are theoretically justiciable in Ethiopia. For more on this, see A Tesfaye Justiciability of socio-economic rights in the Federal Democratic Republic of Ethiopia (2010) 88. Others argue that the FDRE Constitution limits the power of courts. Courts in Ethiopia do not have the power to undertake judicial review, and their power to interpret the Constitution has been given to the Council of Constitutional Inquiry $(\mathrm{CCl})$ and the House of Federation. There are instances where a matter alleging a violation of fundamental rights contained in the Constitution is brought before a court and the court refers the matter to the $\mathrm{CCl}$. For more on this, see C Mgbako 'Silencing the Ethiopian courts: Non-judicial constitutional review' (2008) 31 Fordham International Law Journal 266, https:// www.academia.edu/26494018/Silencing_the_Ethiopian_Courts_Non-Judicial_Con stitutional_Review_and_its_Impact_on_Human_Rights (accessed 9 April 2019). Also see $\overline{A K}$ Abebe 'Access to constitutional justice in Ethiopia' in PS Togia et al (eds) (2014) 64, https://www.academia.edu/18708196/Access_to_constitutional_ justice_in_Ethiopia. Also see Dawit 'Adjudication of FDRE Constitution' https:// www.abyssinialaw.com/component/k2/itemlist/user/734-dawit (2019) (accessed 9 April 2019).

114 One of the reasons for this is the narrow space for civil society and strict funding and membership limitations of civil society that work on human rights protection. See Abebe (n 113) 65-66. 


\section{A right to food response to land-grabbing}

In this part of the article the author first analyses how the different stages of land-grabbing threaten the right to food. Following that possible responses to the threat posed by land-grabbing, such are titling and export restriction, are critically analysed. Finally, various measures are suggested, taking into account the available interdisciplinary knowledge related to agriculture. The author advocates the need for a human right to land and the legal recognition of various uses of land. In addition the positive role to be played by investors is highlighted.

As discussed above, the right to food can be realised in two ways, namely, by directly feeding oneself using natural resources or by purchasing food for consumption. From this it may logically be inferred that preventing someone from being able either to feed themselves or to purchase food is a prima facie violation of the right to food. The ability to utilise land for cultivation or grazing is an important element of the right, especially in a predominately agrarian country such as Ethiopia. Therefore, the government has a duty to respect, protect and fulfil this element of the right. ${ }^{115}$ The former UN Special Rapporteur on the Right to Food, Olivier de Schutter, links land-grabbing and the violation of the right to food as follows: ${ }^{116}$

The human right to food would be violated if people depending on land for their livelihoods, including pastoralists, were cut off from access to land, without suitable alternatives; if local incomes were insufficient to compensate for the price effects resulting from the shift towards the production of food for exports; or if the revenues of local smallholders were to fall following the arrival on domestic markets of cheaply priced food, produced on the more competitive large-scale plantations developed thanks to the arrival of the investor.

This statement indicates that the effect of land-grabbing on the right to food goes beyond disabling those who depend on land to feed themselves. It also adversely affects poor local consumers who rely on the food market if the crops produced are destined for export. Smallholders that are unable to compete in the market with large commercial farmers are also affected if the crops are dumped on the local market. This opens up a dilemma as to what the response of states should be to overcome the negative effects of land-grabbing. That is the dilemma of opting to export crops produced on large investor farms at the expense of risking local food security, or opting for restricting exports at the risk of jeopardising the livelihood of small farmers that cannot compete on the local market with large investors. This in turn raises the bigger question of the possibility of co-existence of large-scale industrial farms and small-scale family farms without

115 FIAN Land-grabbing in Kenya and Mozambique (2010) 11.

116 Report of the Special Rapporteur on the Right to Food, Olivier de Schutter 'Largescale land acquisitions and leases: A set of minimum principles and measures to address the human rights challenge' (2009) para 4. 
threatening the right to food. ${ }^{117}$ De Schutter, who proposed a paradigm shift that dismisses both options, made this observation. ${ }^{118}$ However, before exploring this, it is necessary to illustrate how the pertinent stages of land-grabbing threaten or violate the right to food in the Ethiopian context, that is, the negotiation and conclusion of the land lease, and the displacement of local communities.

\subsection{Negotiation and conclusion of the deal}

The Ethiopian government exercises control over land as the custodian on behalf of the public. Thus, large-scale land deals are concluded between the government and investors. ${ }^{119}$ Farmers with titles over their land can also lease the land for a short period. However, since customary land rights are not fully recognised, in cases where such land users are concerned, the government has exclusive legal authority to lease the land. ${ }^{120}$ Hence, it is the government that decides whether land is underutilised or idle and destines it for investment. According to the government, most of the land given to investors is deemed unutilised land. ${ }^{121}$ However, the data used to determine land availability lacks credibility. ${ }^{122}$ It does not take into account the multiple uses of the land by peasants and agropastoralists. $^{123}$ In addition, such data as well as satellite-based land demarcations underestimate land used for shifting cultivation and land used by pastoralists. ${ }^{124}$ Hence, this entails the displacement of people from the land they use for subsistence and the loss of grazing land, forest resources and water resources that are vital for the livelihood and survival of communities. ${ }^{125}$

The protection of the right to adequate food demands that the government acts in accordance with principles of accountability, transparency and people's participation. ${ }^{126}$ When states take measures that are aimed at or that are likely to affect local food security, they have the obligation to inform and consult all relevant actors. $^{127}$ Furthermore, as far as indigenous people are concerned, their ancestral land should not be confiscated without their prior free and informed consent. ${ }^{128}$ This entails conducting consultations in a way that is understandable to the indigenous community and

117 O de Schutter 'How not to think of land-grabbing: Three critiques of large-scale investments in farmland' (2011) 38 The Journal of Peasant Studies 259.

118 As above.

119 Oakland Institute (n 2) 25.

120 Cotula (n 36) 16.

121 Oakland Institute (n 2) 17.

122 Rahmato (n 52) 7-10.

123 As above.

124 Cotula (n 36) 17.

125 Oakland Institute (n 2) 38.

126 ESCR Committee General Comment 12 para 23.

127 Golay \& Biglino (n 95) 1633.

128 'Respecting free, prior and informed consent Practical guidance for governments, companies, NGOs, indigenous peoples and local communities in relation to land 
acquiring their consent without any kind of intimidation or duress. ${ }^{129}$ In other words, if they do not consent, their land should not be confiscated. However, the Ethiopian government does not inform or consult with the local population before giving land to investors. ${ }^{130}$ Due to the lack of consultation, the views and interests of the land users are not taken into consideration in land deals. As the government is the custodian of land on behalf of the people, meaningful consultation is necessary to identify whether a certain project is in the public interest or not. Studies conducted in the Gambella and Oromia regions, as outlined in part 2, are an indication of the need for accountability, transparency and participation.

\subsection{Displacement and loss of livelihood}

Land-grabbing has led to the displacement of hundreds of thousands of rural dwellers, including farmers, pastoralists and indigenous people in Ethiopia. ${ }^{131}$ The main concern expressed by displaced people is the lack of food in their new locations. ${ }^{132}$ Furthermore, the new locations mostly are far from water sources and access to farming land is not guaranteed, and if it is, the land more than likely is much less fertile. ${ }^{133}$ If communities that rely on land for subsistence are displaced, they should receive adequate compensation and arable land that takes into consideration the type of cultivation suitable to the geo-climatic condition of the area. If this is not done, communities that were able to feed themselves will be vulnerable to hunger and will rely on food aid, as evidenced in the Gambella, SNNPR and Oromia regions of Ethiopia. ${ }^{134}$ This amounts to a violation of the duty to respect the right to food since it entails an action by the state that deprives individuals of access to productive resources. ${ }^{135}$

At this juncture the jurisprudence of the African Commission deserves closer examination. In the Endorois case ${ }^{136}$ the Commission found that the displacement of the Endorois people, an indigenous pastoralist community in Kenya, for the erection of a wildlife reserve and their transfer to a semi-arid area that is not suitable for pastoralism threatened their survival and violated several rights in the

acquisition' Food and Agricultural Organisation of the United Nations Governance of Tenure Technical Guide No 3 4-5.

129 As above.

130 Rahmato (n 52) 5.

131 Anywaa Survival Organisation 'Land-grabbing and violations of human rights in Ethiopia' http://www.anywaasurvival.org/land-grabbing-and-violations-of-humanrights-in-ethiopia/ (accessed 19 October 2016).

132 Oakland Institute (n 2) 40.

133 Anywaa Survival Organisation (n 131).

134 As above.

135 Golay \& Biglino (n 95) 1634.

136 Centre for Minority Rights Development \& Others v Kenya (2009) AHRLR 75 (ACHPR 2009) paras 235, 238, 244, $268 \& 298$ (Endorois case). 
African Charter, including their right to property and the development and their right to natural resources. ${ }^{137}$ Although the African Commission did not find a violation of the right to food, it made the crucial link between the displacement of an indigenous community form ancestral land, their loss of livelihood and the threat to their survival. This link is important for the realisation of the right to food of such communities. Furthermore, the Commission took a strong stand on land rights, inspired by the UN Declaration on the Rights of Indigenous Peoples and the jurisprudence of the Inter-American Court of Human Rights. It stated that 'the jurisprudence under international law bestows the right of ownership rather than mere access'.138 The African Commission further stressed the issue of peoples' participation by stating that 'ownership ensures that indigenous peoples can engage with the state and third parties as active stakeholders rather than as passive beneficiaries'. ${ }^{139}$

This jurisprudence is relevant to the displacement of indigenous people in Ethiopia. The Ethiopian government does not recognise an ownership right of indigenous people to their ancestral land and, therefore, easily displaces them without consultation and compensation. Recognising the ownership right of these communities is paramount for their protection. The justification given by the Ethiopian government is the same as the justification given by the Kenyan government: In both cases the displacement was done in the 'public interest'. ${ }^{140}$ Kenya and Ethiopia share a similar situation when it comes to the displacement of indigenous communities for 'developmental' reasons or for 'public interest'. The Omo Valley of Ethiopia, where indigenous communities affected by land-grabbing are located, extends into Kenya. Indigenous communities on the Kenyan side of the region find themselves in a similar situation. ${ }^{141}$ The ruling and findings of the African Commission in the Endorois case may be used to challenge the land-grabbing-induced forced displacement of indigenous communities in Ethiopia that has resulted in the loss of their livelihoods and violated their right to adequate food.

In this regard, a communication has been brought before the African Commission against the government of Ethiopia for violations of the rights of indigenous people of the Lower Omo Valley, which discloses the forced relocation of communities to clear land for large plantations and other projects. ${ }^{142}$ The communication has passed the stage of admissibility, ${ }^{143}$ and the African Commission has urged the

137 As above.

138 Endorois (n 136) para 204.

139 As above.

140 Endorois (n 136) para100.

141 Human Rights Watch (n 77).

142 35th Activity Report of the African Commission on Human and Peoples' Rights (2013) 8.

143 As above. 
government of Ethiopia to cease forced relocations while it undertakes an investigation of human rights violations. ${ }^{144}$

When the right to food is violated, states have an obligation to ensure that the victims get access to an effective remedy. ${ }^{145}$ The domestic courts of Ethiopia should also play their part in addressing such violations, which are against the Constitution and international treaties that Ethiopia has ratified. Lessons can be learnt from the jurisprudence of other African countries that are facing similar problems. In the Baleke case the High Court of Uganda dealt with the forced eviction of peasants that had been customary tenants of land in Uganda. ${ }^{146}$ The tenants were evicted against their will and received no compensation. The Ugandan government gave the land to German investors for the establishment of a coffee plantation. Through this act the evicted people lost their livelihoods and faced starvation. The High Court of Uganda held agents of the state liable for the act and ordered compensation to be paid to the 2041 individuals evicted. In addition to finding agents of the state liable for the forced eviction, the Court stated: 147

The German investors had a duty to ensure that our indigenous people were not exploited. They should have respected the human rights and values of people and as honourable businessman and investors they should have not moved into the land unless they had satisfied themselves that the tenants were properly compensated, relocated and adequate notice was given to them. But instead they were quiet spectators and watched the drama as cruel and violent and degrading eviction took place through partly their own workers. They lost all sense of humanity.

This decision exemplifies how courts can ensure private actors' responsibility to respect human rights in accordance with the Guiding Principles on Business and Human Rights. The Guiding Principles require businesses to put in place 'a human rights due diligence process to identify, prevent, mitigate and account for how they address their impacts on human rights'. ${ }^{148}$ The decision also contextualises the specific responsibility placed on private actors in General Comment 12 of the ESCR Committee, which is to operate in a manner that is conducive to ensuring the right to adequate food of locals. ${ }^{149}$

Apart from respecting the enjoyment of the right to adequate food and ensuring an effective remedy for the violation of the right, states have an obligation to take measures to realise the right progressively.

144 African Commission on Human and Peoples' Rights investigates Ethiopia and Botswana' http://www.zegabi.com/articles/5838 (accessed 15 October 2016).

145 Golay \& Biglino (n 95) 1633.

146 Baleke \& Others v Attorney-General of Uganda \& Others (2002) Civil Suit 179 (High Court of Uganda).

147 Baleke (n 146) para107.

148 United Nations Guiding Principles on Business and Human Rights (2011) para 15(b).

149 ESCR Committee General Comment 12 para 20. 
This includes undertaking agrarian reform to ensure the efficient utilisation of natural resources as well as an equitable distribution of food. ${ }^{150}$ The next part of the article explores suggested measures that states can take to realise the right to food in an agrarian society. It also suggests measures to prevent or reduce the negative impact of landgrabbing.

\subsection{Measures for the progressive realisation of the right to adequate food in the context of land use}

One important development after the advent of contemporary landgrabbing is the adoption of the Voluntary Guidelines on the Responsible Governance of Tenure of Land, Fisheries and Forests (Voluntary Guidelines). ${ }^{151}$ The main goals of the Guidelines were to achieve food security and to ensure the realisation of the right to adequate food. ${ }^{152}$ Even though there is no international consensus on tenure rights being human rights, the Guidelines make it clear that tenure rights are important for the realisation of various human rights and, notably, the right to adequate food. ${ }^{153}$

The Voluntary Guidelines complement the Voluntary Guidelines on the Right to Food that were adopted by FAO much earlier with the aim of ensuring the progressive realisation of the right to food. ${ }^{154}$ The addition of the new Guidelines is an affirmation of the necessity to move towards a human rights-based approach to natural resource management, specifically land management. However, these Guidelines have not resulted in a reduction in land-grabbing, mainly owing to their non-binding nature. At the regional level, the Guiding Principles on Large-Scale Land Investments in Africa ${ }^{155}$ urge such types of investments to respect the human rights of local communities.

\subsubsection{Ensuring security of tenure}

There were several suggested responses to the challenges of landgrabbing. One such response was the introduction of titling schemes in rural areas where farmers did not have titles to their land. This emanated from the apparent correlation between weak land tenure security and high levels of land acquisition. ${ }^{156}$ Ethiopia is one of those

150 Arts 11(2)(a) \& (b) ICESCR.

151 'Voluntary Guidelines on the Responsible Governance of Tenure of Land, Fisheries and Forests in the Context of National Food Security' Food and Agriculture Organisation of the United Nations (2012) http://www.fao.org/3/a-i2801e.pdf (accessed 15 October 2016).

152 FAO CFS Voluntary guidelines on the responsible governance of tenure of land, fisheries and forests in the context of national food security (2012) vi.

153 FAO Voluntary guidelines on the governance of tenure at a glance (2012) 8.

154 FAO CFS (n 152).

155 AU Guiding Principles on large-scale land-based investments in Africa (2014) 7.

156 Nolte (n 8) 20. 
countries characterised by weak land tenure security and large-scale land acquisitions. ${ }^{157}$

The aim of the titling scheme is to ensure security of tenure, thereby tackling the problem of a lack of transparency in land deals, and to equip local communities with a tool to exercise their property rights. Ensuring security of tenure will facilitate the realisation of the right to food as well as empower those whose livelihoods depend on land and other natural resources. Through such schemes it was believed that farmers would have greater choice since it will give them the option of selling the land to exit from agriculture. Furthermore, they can mortgage the land and have access to credit, which they can use to invest in the land. ${ }^{158}$ The titling schemes were also believed to increase efficiency as land theoretically would go to the most efficient user through transaction. The Ethiopian government has already conducted the largest nationwide land registration and certification programme in Africa. ${ }^{159}$

However, such schemes may be far from ideal once implemented. There are three main problems with titling schemes. First, land does not necessarily go to the most efficient user but rather to those with the most capital, and the poor are priced out. Hence, these schemes do not always benefit the poor. 160 This means that land may end up in the hands of those who will not make efficient use of it, and it will be deprived by the market from those that would use it efficiently. Small subsistence farmers are the most efficient users of agricultural land. ${ }^{161}$

The second problem is related to its effect on women. Titling places women at a disadvantage because the land is mostly registered in the name of a man who is considered the 'head of the house'. Therefore, it will legalise the traditional disadvantage women face with land ownership and control. ${ }^{162}$ Ethiopia implemented joint titling schemes, which in theory are supposed to ensure equal land rights of women and men. However, the disparities in implementation in various regions and the triumph of gender roles over legal norms have resulted in a disadvantage for women. ${ }^{163}$

The last major problem with titling is that it does not secure the right of access to communal land for grazing, fishing, collecting wood or the rights or interests of those who use the forest for hunting and

157 As above.

158 De Schutter (n 117) 270.

159 S Bezu \& S Holden 'Demand for second-stage land certification in Ethiopia: Evidence from household panel data' (2014) 14 Land Use Policy 193.

160 De Schutter (n 117) 269.

161 FAO (n 153) xi.

$162 \mathrm{O}$ de Schutter 'The role of property rights in the debate on large-scale land acquisitions' (2015) 6 International Development Policy Series 32.

163 Brief: The gender implications of joint titling in Ethiopia' http://www.focusonland. com/fola/en/countries/brief-the-gender-implications-of-joint-titling-in-ethiopia/ (accessed 16 October 2016). 
gathering. ${ }^{164}$ These resources are paramount for the protection of the right to food of various communities in Ethiopia. Forest resources are used as a buffer food supply. Communal grazing lands are crucial for livestock production. Various communities, including indigenous people, practise fishing, hunting and gathering for subsistence. ${ }^{165}$ Hence, it is paramount to consider a right over these resources for the effective protection of the right to adequate food.

The best way to make security of tenure benefit land users without falling in the trap of titling schemes is by distinguishing it from the conventional understanding of property rights. The property rights lens is based on the creation of a market for land rights. However, it should rather be understood as a right that allows communal tenure as well as protecting land users from eviction. ${ }^{166}$ First, the registration of land rights should be based on mapping by the local community. This will ensure that the interests of the local community will be safeguarded, ensuring that grazing, fishing and other activities that are important for the survival and well-being of the community will not be overlooked. However, when mapping is delegated to the local community, it should be done in such a way that the voices and interests of women and other minority groups are equally entertained. Another useful tool to ensure security of tenure is the strengthening of anti-eviction laws to protect land users from forced displacement. It is also important to develop tenancy laws to protect tenants from being evicted and from excessive rental charges and share-cropping. ${ }^{167}$ Finally, the introduction of land reform for solving the excessive concentration of land and reducing rural poverty is advisable. Moreover, the land rights of indigenous communities should be respected irrespective of the lack of titles.

These measures are useful for ensuring land tenure without falling in the pitfall of titling schemes. However, they are not sufficient to combat the food security challenges that result from land-grabbing. The emergence of a human right to land and of different types of land use that recognise the needs of indigenous people, pastoralists and small-scale farmers and ensures gender equality are essential. ${ }^{168}$

\subsubsection{Export restrictions as a solution}

Another response to the negative impact on the right to food of landgrabbing was the suggestion of introducing export restrictions. This is to ensure that food crops produced on large investor farms go to the local market, thereby increasing the availability of local food. ${ }^{169}$ The first challenge to such a measure comes from the World Trade

164 De Schutter (n 162) 31.

165 Oakland Institute (n 48) 8.

166 De Schutter (n 117) 269.

167 De Schutter (n 162) 35.

168 Golay \& Biglino (n 95) 1634.

169 Future Agriculture (n 34) 3. 
Organisation (WTO) rules. Imposing such export restrictions is contrary to the Agreement on Trade-Related Investment Measures (TRIMs) of the WTO. ${ }^{170}$ Even though Ethiopia is not yet a member of the WTO, it has started the process of accession. ${ }^{171}$ Upon accession, the country will be required to fully comply with the requirements under the TRIMs agreement. ${ }^{172}$

Second, the bargaining power of states that compete and desperately try to attract investors is insignificant. States are unlikely to push for such clauses in land deals. In the case of Ethiopia, the government is more interested in the foreign currency that comes with export than any other variable. Hence, there is a strong desire to promote export rather than restrict it. This is evidenced by the incentives given to investors, both local and foreign, who export their products. $^{173}$

The above impediments make the proposed solution of imposing export restriction difficult and unlikely to be implemented. Moreover, even if somehow it is implemented, such a restriction on export may not necessarily solve the problem of local food security. The food security challenge that emanates from land-grabbing is mainly due to the loss of livelihoods of rural communities. As stated before, the right to food is 'violated if ... the revenues of local smallholders were to fall following the arrival on domestic markets of cheaply priced food, produced on the more competitive large-scale plantations'. ${ }^{174}$ Therefore, imposing restrictions on food exports and dumping food on the local market are not solutions for net food-seller ${ }^{175}$ farmers. ${ }^{176}$ It may be desirable for small-scale farmers that are net food buyers. However, there is a large population of net food sellers that will be disadvantaged. ${ }^{177}$ The majority of small-scale farmers in Ethiopia who produce food crops are net food sellers, and the dumping of food on the market by large investors will oust them from the market and threaten their livelihood.

170 TRIMS Agreement: Agreement on Trade-Related Investment Measures 1994 art 2.

171 WTO Accessions https://www.wto.org/english/thewto_e/acc_e/acc_e.htm (accessed 20 October 2016).

172 United Nations Conference on Trade and Development Elimination of TRIMs, the experience of selected developing countries (2007) 111.

173 Makki \& Geisler (n 21).

174 De Schutter (n 117).

175 'A household which is a net-seller of food staples is defined as a household that sells more food on the market either in weight or in value (that is quantity times price) than what they buy on the market for a given season or a year, either in relation to a single staple or to a combination of staple foods - depending on how one wants to construct the profile. A household that is a net-buyer buys more food staples (either in weight or value) on the market than they sell for a given season or a year. Urban households, for example, are typically characterised as net-buyers as they often do not produce their own food and rely mostly on markets to buy their food.' See 'How to estimate household net-seller/buyer status and the welfare impact of shocks?' (2019) World Food Programme 3.

176 La Via Campesina Declaration of rights of peasants: Women and men (2009) 3.

177 M Aksoy \& A Isik-Dikmelik Are low food prices pro-poor? Net food buyers and sellers in low-income countries (2008) 14. 
Therefore, the government has to find a balance between imposing restrictions on exports, thereby risking threatening the livelihoods of local small-scale producers through internal dumping and, on the other hand, not imposing any export restrictions, but in the process threatening the local food availability.

\subsubsection{Investing in small-scale farming}

In analysing the various suggested solutions to land-grabbing, it was revealed that neither titling nor restrictions on exports provide an adequate solution in addressing the issue. The inadequacy of these measures poses the bigger question, namely, the desirability of the co-existence of small-scale labour-intensive farming and large-scale mechanised commercial farming. ${ }^{178}$ In fact, various principles and guidelines that were introduced to regulate and provide a human rights-based standard to large land acquisitions faced continuous criticism from civil society and agrarian associations for legitimising land-grabbing instead of denouncing it. ${ }^{179}$

For various reasons, small-scale family farming is favoured and believed to be the best way of ensuring the right to adequate food. It is also the best way to reduce rural poverty, as the reasoning below demonstrates. First, most of the world's poor are smallholder farmers, and this is also true for Ethiopia. Investing in improving their livelihood directly contributes to the reduction of rural poverty. ${ }^{80}$

Second, small-scale farming promotes the creation of employment because its methods are labour-intensive as opposed to large-scale commercial farming, which is characterised by the use of machinery. A study conducted on the alleged benefits of large-scale land acquisitions in Africa has shown that they do not result in as much employment as they promise. ${ }^{181}$

Third, small-scale family farming has stronger multiplier effects in the local economy. An increase in the income of smallholders will develop the market for local service providers and local industries. ${ }^{182}$ On the other hand, if all the benefits of a large piece of land went to one landowner, they are more likely to invest it in luxury products or large machinery that will not have a multiplier effect in the local economy.

Fourth, small-scale family farming is highly productive per hectare. This is partly because smallholders make the best out of the limited resources they have available to achieve the best possible outcome, ${ }^{183}$ when measured in terms of resource productivity and not labour productivity. Studies reveal an inverse relationship between the size of

178 De Schutter (n 162).

179 De Schutter (n 162) 254.

180 FAO Strategic work of FAO to reduce rural poverty (2016) 4.

181 Cotula (n 36).

182 De Schutter (n 162) 5.

183 De Schutter (n 117) 260. 
a farm and total productivity. ${ }^{184}$ Finally, small-scale farms are better for environmental conservation as they are aligned with agroecology. ${ }^{185}$ The environment is directly liked to food production, and protecting it and ensuring sustainability enhance accessibility of food for both current and future generations. ${ }^{186}$ Small-scale family farmers use methods of crop rotation and shifting cultivation in addition to combining crop production with livestock production. This protects the soil and enhances productivity. ${ }^{187}$ On the other hand, large-scale mechanised farms practise mechanised monoculture, resulting in soil erosion and pollution. ${ }^{188}$

This does not mean that foreign and other private investors have no positive role to play. There are various ways in which investors can invest in farm land without necessarily taking control of the land and changing its use, in other words without grabbing land. One such way is contract farming. This allows farmers to benefit from investment without losing access to their land, and if properly managed, it can provide a win-win situation. ${ }^{189}$

An experience from Mali indicates such a possibility. A company named Biocarburant SA bought land to build a processing plant for the production of bio-fuel from Jatropha. ${ }^{190}$ Through collaboration with local farmers' cooperatives, the company processes Jatropha that is produced by the farmers themselves on their own lands. The farmers have a share in the bio-fuel production. Furthermore, the growing of Jatropha does not threaten their food security, as it is a plant that can be intercropped with maize. ${ }^{191}$ This type of investment respects the land use of the farmers, does not threaten their food security since the type of bio-fuel crop produced is one that can be cultivated with a food crop, and benefits the farmers by creating a market for their produce and giving them a share in the investment.

\section{Conclusion and recommendations}

Land-grabbing in Ethiopia is a gross violation of the right to adequate food. The government is transgressing its duty to respect the right by

184 Industrial agriculture, agro-ecology and climate change' https://www.ecoliteracy. org/article/industrial-agriculture-agroecology-and-climate-change (accessed 22 October 2016).

185 'Only small farmers and agro-ecology can feed the world' https://www.tni.org/en/ article/un-only-small-farmers-and-agroecology-can-feed-world (accessed 16 October 2016).

186 ESCR Committee General Comment 12 para 7.

187 Industrial agriculture, agro-ecology and climate change (n 184).

188 As above.

189 De Schutter (n 117) 262.

190 'Commercial Jatropha biodiesel production with small-scale farmers' http://www. worldagroforestry.org/sites/default/files/grp1_workshops/Trees\%20for\%20Farmers /G.\%20Poster\%20exercise/Posters/Ard\%20Lengkeek.pdf (accessed 22 October 2016).

191 De Schutter (n 117) 262. 
forcefully evicting communities from the land they rely on for subsistence and relocating them in an unfavourable environment with no compensation for their loss. It also takes away vital resources such as water, forests and grazing land and handing it to investors. The investment in farm land does not in any way improve the lives of these local communities. It does not result in an improvement in services and infrastructure. The little employment that they create are jobs that pay salaries that are considered below the poverty line. Furthermore, taking into account the advantages and disadvantages of large-scale commercial farming for which land is being grabbed, the priority given to it is not in line with the duty of the government to take appropriate measures for the progressive realisation of the right in line with available scientific knowledge.

The Ethiopian government should undertake agrarian reform aimed at empowering small-scale farming. In particular, land registration should be revisited to incorporate communal land use. It should also take into account the importance of grazing land, water sources, shifting cultivation and other practices necessary for livelihood. Furthermore, the gender gaps of joint land registration, in the implementation phase, should be rectified. Agricultural extension programmes aimed at smallholders should be strengthened and expanded.

Agricultural investments should not in any way jeopardise local food security or lead to the forced displacement of communities and their relocation to a less favourable environment. The 'villagisation' or forced relocation programme should be halted immediately and those who are displaced should be reinstated or compensated adequately. If relocations are carried out, the government should ensure that it is indeed beneficial for the public through consultation with those directly affected. Furthermore, the government should adopt rules and procedures in accordance with the Basic Principles and Guidelines on Development-Based Evictions and Displacement. The rights of indigenous people to their ancestral land should be respected. They should not be relocated without their full consent. Furthermore, the government should put in place mechanisms to ensure transparency and good governance in land management. Moreover, the civil society space should be widened, allowing for agrarian-based civil societies to be able to advocate human rights.

In addition, farm land investors must recognise their responsibility to conduct their activities in a manner that does not violate human rights. In particular, they should create a human rights due diligence process to prevent any violations. Furthermore, they should agree upon a code of conduct with the government in collaboration with civil society as well as local community representatives, to ensure that their activities do not in any way jeopardise the enjoyment and progressive realisation of the right to adequate food. 